\title{
Coronavirus Pandemic 2019: Histological Similarities to Precursors, Repercussions of Politicizing an Intricate Medical Event and the Anticipated Induced Damage to Societal Fabric
}

\author{
JH Wassili and Cyril Baradaeus* \\ The Samaritan Biochemists, 279 Khaled ben Waleid, Alexandria, Egypt
}

*Corresponding author: Cyril Baradaeus, The Samaritan Biochemists, 279

Khaled ben Waleid, Seidi Gaber, Alexandria, Egypt.

Received Date: May 14, 2020

Published Date: June 24, 2020

\begin{abstract}
This is a concise review to current scientific elaboration on organic structural similarities of the recent health Covid-19 menace to early viral plagues, SARS, EVD and AIDS, possible link to MIS-C together with conceivable embroidering, within experimental uncertainties, on the unpremeditated insults of psychological damage to the societal fabric.

Abbreviations: Coronavirus Pandemic 2019 (Covid-19); Severe Acute Respiratory Syndrome (SARS); Ebola Virus Disease (EVD); Acquired Immunodeficiency Syndrome (AIDS); Multi-System Inflammatory Syndrome in Children (MIS-C); Biomedical advanced research and development authority (Brada); Kawasaki Disease (KD); Constantine-II (C-II); Belt and Road Initiative (BRI); Post traumatic stress disorder (PTSD)
\end{abstract}

\section{Introduction}

As organic chemists, it is our contention Covid-19 will stay with us. Thus, it is more conceivable to expedite means to find a safe medication to the afflicted and a vaccine to protect the healthy individuals, specifically the children and the elderly vis-à-vis the exaggerated politicization of this intricate issue by medical science illiterates. Covid-19 became a Freudian-allusion of toxic self-praise, e.g., the bombastic claim of a chemistry illiterate pointing to his head "the metrics are right here". Not very surprisingly, earlier in a pseudo Messianic communication; the trials of the FDA-unproven drugs on humans-rodents with last stage diseases à la J Mengele was suggested. That is indicative of an urgent drafting of an in-depth Freudian counselling. Alas, at K2+20, in lieu of research laboratories, the media became the political-circus for the management of Covid-19. Finally, political marketing of hydroxychloroquine could be a conflict of interest. It is the contractors' mentality: why waste time if you can buy it? Rather than toiling hard to get the best of the 1000s of the most qualified US biomedical scientist, let us buy it from the Germans! A German government source confirmed the U.S. "was looking into how it could gain access to a potential vaccine being developed by a German firm, CureVac that is developing of an mRNA-based vaccine against Covid-19. That is the effective biomedical management(s) of Covid-19 were kidnapped from research laboratories and hospitals to become a hostage to political maneuvering and misleading bombardments of megalomaniac claims in televised press-conferences à la PJ Goebbels.

Irresponsible claims and (a) personal targeting and cutting the research funding of Dr. Daszak at this particular time is rather suspicious as utterly delaying the management of Covid-19. In 2003 interview, Dr. Daszak expressed his worries: the most is that we are going to miss the next emerging disease that we are suddenly going to find a SARS virus that moves from one part of the planet to another, 
wiping out people as it moves along, (b) firing R Bright, Brada's chief, who toiled to develop a coronavirus vaccine on the account of his refusal to substantiate the relentless political advertising of the unproven hydroxychloroquine as a medication to Covid-19, and (c) personalizing the Covid-19 issue with the federal government's top infectious disease expert, post Dr Fauci's comments to a Senate hearing about the entailed risks to the children should schools are reopened.

Cutting the research funding of Dr. Daszak and firing Bright are in sharp contradiction to the:

- $\quad$ scientific grandiose of September 12, 1962. At the peak intellectualism it was decided "We set sail on this new sea because there is new knowledge to be gained, and new rights to be won, and they must be won and used for the progress of all people. For space science, like nuclear science and all technology, has no conscience of its own. Whether it will become a force for good or ill depends on man, and only if the United States occupies a position of pre-eminence can we help decide whether this new ocean will be a sea of peace or a new terrifying theater of war". Alas, current improvement of rockets' velocity was envisaged and reduced by the science-illiterates to a restaurants' chef barbequing a super-duper hamburger. Most likely, considering the characteristic famished-intellectualism of the two eras; two goat heads will not differ: the time-line for the pathetic political-failure to deal with either the HIV/AIDS (1981-1989) and the Covid-19 (Dec 31, 2019 first case reporting to WHO2021) is not fortuitous. The current mental decline is rather critical, viz., (A) endless hounding of the fundamentals of

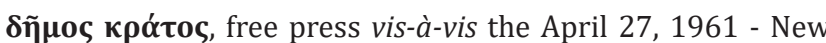
York City eloquent speech of JF Kennedy pertaining to the ethics of journalism and Secret Societies at a NY city gathering and (B) the mindless disembowelment of the basic decency of the US-culture, e.g., the inflammatory statement which could be regarded as a veiled call for violence 'When the looting starts, the shooting starts' vis-à-vis the Indianapolis, Indiana April 4, 1968 speech: I have bad news for you, for all of our fellow citizens, and people who love peace all over the world, and that is that Martin Luther King was shot and killed tonight. In his memorable speech RFK quoted Aeschylus "In our sleep, pain which cannot forget falls drop by drop upon the heart until, in our own despair, against our will, comes wisdom through the awful grace of God". In this context, it is pertinent to call the current anti-racism riots: "the USA-Spring"? The participants in this massive civil disobedience were shouting "Vote him Out" as the 2013-Egyptians were calling on Mursi "Irhal, that is leave". Both events share the same causative factor: Injustice. The killing of Khaled Mohamed Saeed (Alexandria 2010) and Menas Daniel (Maspero Cairo 2011) by the police and army troops respectively sparked the Egyptian revolt, as mush the killing of G Floyd by the police fermented the current riots in the USA. To top it, demonstrations calling for the urgent societal management of the malaise that culminated into the death of George Floyd were ridiculously demoted by Attorney General W Barr to abuse by the left wing and Antifa sympathizers. Obviously, the bombast is abusing the G Floyd incident to cover up the utter failures of the past 4 years, listed below", and

- typically, according to the good gesture "someone wants your tunic, let him have your cloak and if someone wants you to go one mile, go with him two", on $22^{\text {nd }}$ March, C-II mobilized a massive Russian support to Italy's battling of the horrendous infestation of Covid-19. Although, labelled "From Russia with Love", it was typically Hollywood smeared as "looks more like espionage". The Russian medical team successfully accomplished the assigned task and returned to base vis-à-vis the 20-years failure of violent stay in Iraq. Nonetheless, this Italian-Russian event marked a substantial intercontinental collaboration to encounter a serious medical plague as of the assassination of Aldo Moro.

As of the incipience of Covid-19 in the USA, in a broken-record like, the science-illiterate on weekly basis bombastically claimed: next week's Covid-19 contraction/ or expiry of patients would become the momentous week in the fight against the coronavirus. To make things worse, an irresponsible prediction, the K Hassett's model, concluded zero deaths in the U.S. from the Covid-19 by May 15. Although he is not a qualified scientist, the Hassett's predictive model, among others, regardless of causalities, may be the pivotal factor in reopening facilities to assume normalization. All the relevant data is abundantly available in the literature, as organic chemists we are rationalizing events, hopefully in a reasonable format. Unfortunately, valuable time was consumed by the science-illiterates into flashy oratories climaxing into the failure of the Hassett's predictive model to account for the medical health deterioration to precipitate MIS-C. incidentally in isolated clusters (in N.Y. not Wuhan China), children developed MIS-C. With some certainty, it is safe to assume, on the account of rampant poverty and a broken medical care system dominated by the medicalinsurance scavengers, MIS-C was localized in isolated clusters in NY not Wuhan China). Children stricken by MIS-C showed some similarities to a rare childhood condition, that is KD. Although, KD is a different illness, it is a leading cause of acquired heart ailment in infants and young children. Scientists and MDs found it to shares some of the same symptoms with MIS-C, namely, trouble breathing, gastric disorders, fever, confusion and skin rash.

According to above data and below observation, it is most pertinent to entertain the Morten Moshagen's D-factor model. Morten Moshagen and his colleagues defined the D-factor as the basic tendency to maximize one's own utility at the expense of others, accompanied by beliefs that serve as justifications for one's malevolent behaviors. In their definition, utility refers to goal achievement. For those scoring high on the D-factor, utility maximization is sought despite running contrary to the interests of others or even for the sake of bringing about negative outcomes in others. 


\section{Discussion}

To thoroughly comprehend the genesis of Covid-19 and alleviate if possible the anticipated organic and societal damage, the available observation points to a 3 -folds discussion, very briefly:

\section{Proteomic inquiry revealed}

(a) Protein chemistry and sequence reanalysis of Covid-19 genome has a unique similarity of its spike protein insertions to HIV-1 and rebuts the notion of snakes as its intermediate host (1). Structural similarities between HIV-1 gp41 and SARS-CoV S2 proteins suggested analogous mechanisms of membrane fusion (2). In an earlier work, influenza virus was pseudo typed with EVD glycoprotein (3). Regardless of this dedicated scientific research, laypersons are confronted with an avalanche of misleading claims from science-illiterates. These claims are expected to dilute the recovery from Covid-19 and multiply the mortality therefrom, viz., a chronological brief below:

- "Coronavirus is going to disappear. One day, it's like a miracle, it will disappear." Feb. 28, 2020,

- $\quad$ Now, the virus that we're talking about having to do, you know, a lot of people think that goes away in April with the heat, as the heat comes in. Typically, that will go away in April. We're in great shape though." Feb. 10, 2020,

- $\quad$ "Anybody that needs a test can have a test. They are all set. They have them out there. In addition to that they are making millions more as we speak but as of right now and yesterday anybody that needs a test that is the important thing!" March 6 2020. Nonetheless, director of the National Institute of Allergy and Infectious Diseases contradicted this claim,

- The favorite rancid tune of blaming China. It was communicated: "I always treated the Chinese Virus very seriously and have done a very good job from the beginning, including my very early decision to close the borders' from China, against the wishes of almost all. Many lives were saved". March 18, 2020, and

- Worse, to cover up for the obvious wave of unprecedented failures to protect the populace specifically the young and the elderly, locally the blame was darted to the opponents "Now the Democrats are politicizing the coronavirus. You know that, right? Coronavirus. They're politicizing it ... And this is their new hoax." Feb. 28, 2020

Needless to say, the cover-up to the failure of early management of Covid-19 and saving lives of the young and the elderly became an intense political rhetoric of blaming the Chinese virus! Worse is the threating megalomaniac vocal measure of taking China to court over immaterial claims pertaining to Covid-19 plague. This is mainly a last minute desperation to hype the laypersons (prior to November 2020) to the singlehanded Don quixotic courageous duel to tame the Chinese dragon/and if possible goad the Chinese treasury to pay for the disastrous consequences of an already bankrupted economy. On several occasions; the US economy was boasted to be the strongest, the best and the superiorly most robust economy in the world, every $2^{\text {nd }}$ week of the last 4 years. Alas, both the economy and the societal fabric are coffined in plentiful of flagrant inaccuracies which may prompt the eclipse of capitalism. It is rather a political adolescent tactics as much as vulgarly yahooing "Mr. Gorbachev, tear down this wall!" vis-à-vis the subtle, however vivacious and ethical formulations as potent as an atom explosion: "Ich bin ein Berliner".

As unbiased organic chemists, we are reflecting on the current social unrest in proportion to abundant environmental ruin, scarcity of natural extracts, and the ever multiplying young generations who are deprived of their given birth rights to free medical care and education. At this particular point of time, it is safe to assume Covid-19 became a blessing to dissociate from the befalling worldwide disasters and acute strategical failure. Understanding the sadistic psychology of the current all-knowingly individual, most likely the blunders listed below are well tailored to precisely surface within the last two years' window of time. Together with the anticipated long-range side effects, these blunders unmasked: (I) a pathological range of multiplying insecurities which swarmed the early childhood and (II) the obvious inadequacies to grasp the finite spectrum of mechanisms pertaining to a particular dogmatic trend and the societal multidimensional drives that are contrasting and systematizing the complexities of the current political bends:

- The utter failure of the proposed Peace to Prosperity: (A Vision to Improve the Lives of the Palestinian and Israeli People) to deliver a marginal, not to mention a substantial, improvement in a land soaked with 1400-years of hatred. Scrutiny of relevant literature reveals the number of Israeli fatalities post the mongoloid Kamp-David peace accord exceed the total Israeli causalities in 48, 56, 67 and 73 wars altogether.

- $\quad$ The failure to dismantle the Nuclear Arsenal of North Korea whose president was lately denoted as a "dear friend/" and on an earlier occasion in a UN formal gathering of various heads of the states was surreally referred to as the "rocket man".

- While dancing in lust to the thunderous melodies of obliterating war, the failed economic embargo against Iran prompted the latest drama of killing a Persian general in Iraq à al the theater of killing the chronically kidney-diseased Ben-Laden. The utter failure to deal with the Persian Nuclear Ambition turned into a burning haunting reminder of the many failures, indeed.

- What is the palatable outcome of Mexican Wall, if it were built as hypothesized by the Mexicans 4 years earlier?

- The failure to Syphon the Europeans' Treasury on the account of NATO is providing a free national defense to their borders.

- Although scientifically ridiculed as a therapy to Covid-19, why Hydroxychloroquine in particular? While ignoring the very many scientists and medical doctors who are toiling to develop a medication and possibly a vaccine? In a puritan routine of scientific publications, authors submitting a manuscript for circulation have to oblige to the statement "no conflict of interest 
- It a feverish escalation to blame the WHO and China for the spread of the Covid-19 virus and deflect responsibility for maladroit handling of this particular public health crisis that has killed $>$ 90,000 people in the USA, a four-page threat threat to permanently cut off U.S. funding was communicated to the WHO. Other members rebuffed the emotionally charged memo. Punitive measures against an international organization take more than a determined campaign to smear local experts, e.g., Dr. Daszak, R Bright, Dr Fauci's, etc.

- Management of Covid-19 became a broken record of absurdity. Lately, high US Covid-19 numbers were denoted a "badge of honor" because it means more local testing was done than in any other country in the whole world!

As per above 1-8 of the very many, no one is to blame for adopting and circulating a range of agreeable conspiracy theories, e.g., possible bioterror (4)? In absence of transparent communicating of the findings of balanced scientific pursuits, conspiracy plots are inevitable, indeed. Why not? Considering the enormous damage done to the Chinese BRI, the same routine which (a) justified communicating with foreign authorities to investigate a family member of a leading political rival (any ethics to the call MAGA? 5) and (b) negotiation with dogmatic militants to release the 52 US embassy staff in bondage exactly five minutes after a contender took the oath of office (6), Covid-19 is by all means a potent option to disembowel the Chinese BRI. Together with the current revelations of approaching the Chinese authorities to lend their support to a second term re-election, viz., "The Room Where It Happened: A White House Memoir" are indicative of a maimed childhood.

\section{The societal dogmatic rational of Covid-19}

Reactions to Covid-19 response documented the backwardness of many quarters. At every level with recessed economy of a densely 105 million populated nation, the Egyptian authorities, have skillfully contained and minimized both the contractions and death by Covid-19 during the Easter and Ramadan festivities, viz., the even handed approach executed by the Iron Lady, Dr. H Zayed. Nonetheless, many events of ludicrous dogmatic convulsions surface. For example.

a. On the account of Covid-19, Church attendance during Easter was correctly redistricted. Nevertheless, photographs were circulated of a priest and a high-ranking bishop visiting their local community members for Easter blessings without giving the least good example of wearing masks, divinely immune to Covid-19?

b. A low IQ Egyptian happened to be melting in his soup of illustrious dogmatism while compulsorily tailoring a 1500 years past arid-dogmatic rituals as a "heavenly memorable litmus to the foretelling" of the medical intricacy of the year $2 \mathrm{~K}+20$; Covid-19. The litmus is the current recommended protection to evade contracting Covid-19; namely wearing masks, frequent rinsing of hands and eyes. In effect, Subhanallah, these current health precautions are synonymous with the dictates of Niqāb burka and ablution, he boastfully wondered? That is rather a childish arrogance. In male dominated cultures, the Niqāb was specified for females to cover their beauty so as not to evoke sinful inclinations into the highly imaginative male believers! What is then the plausible rational for men to wear Niqāb burka? Furthermore, with regard to the ritual of ablution, it was a well-known and daily practiced sanitary routine by the Ancient Egyptian, Jews and Christians. Currently, many believers share the same pool of still filthy water for the ritual of ablution and if water is not available, sand is used!!! Most absurd was the visualization of Covid-19 as Allah's army of tiny mujahedeen who were recruited to punish the atheist Chinese for committed crimes against the believers of the Uighur community. Compared to similar mythologies of distant times, this Allah's army of tiny mujahedeen was not very selective as many victims were the believers of the same faith. The least expected was an evident marking the dwelling of members of the Ummah's community, worldwide. If materialized, that would suggest a license to Covid-19 to spare infecting the believers? Worse is the open defiance of Ismaeil Abou Hadid, the secretary general of the radical Salafi-Nour party (Giza/ Cairo branch) to the government imposed "gathering restriction" to limit the spread of Covid-19. He encouraged the believers to gather in group prayers as immune to Covid-19 suggesting only Kafirs/ Infidels would contract the virus.

\section{The Societal Imperative}

The expected societal repercussions are two-folds: increased (a) frequencies of pregnancies on the account of newly found intimacy and nature's reaction to the impending threat Covid-19induced fatalities and (b) wave of domestic violence against women and children of restrained families $[7,8]$.

\section{Conclusion}

The misinformation, the rancid political rhetoric blaming the Chinese and threating measures of taking China to an international court to judge the case of a suggested Covid-19 complexity were a cover up to an acute strategical failure in time the world was yarning for wise management of the medical events. It is a sad saga of internal failure to contain the ghoulish outbreak of Covid-19, specifically among the US-homeless. The Los Angeles Times discussed the spread of Covid-19 among the homeless community, viz., 5000 homeless are crammed into the Skid Row quarters of Los Angeles; portraits below. Worse is: (a) 4.25\% of the world population inhabits the USA, however US is the world leading jailer as US prisons accounts for $25 \%$ of the world's prisoners, viz., figures below! And (b) according to the extracted Figures below, individuals of minority groups compromise the majority of incarcerated individuals. That is the cut-rate manpower of the past cotton field is currently replaced by the incarcerated? Viz., Ava Marie DuVernay's 2016 documentary - Histroy the $13^{\text {th }}<\mathrm{https}$ :// en.wikipedia.org/wiki/13th_(film)>; Were any measures taken by MAGA to protect the prisoners against contracting Covid-19? Furthermore, according to the conspiracy theories, the covid-19 came in the right time to dilute the plague of political failures. Namely; Disembowel the Chinese economy specifically the BRI. 

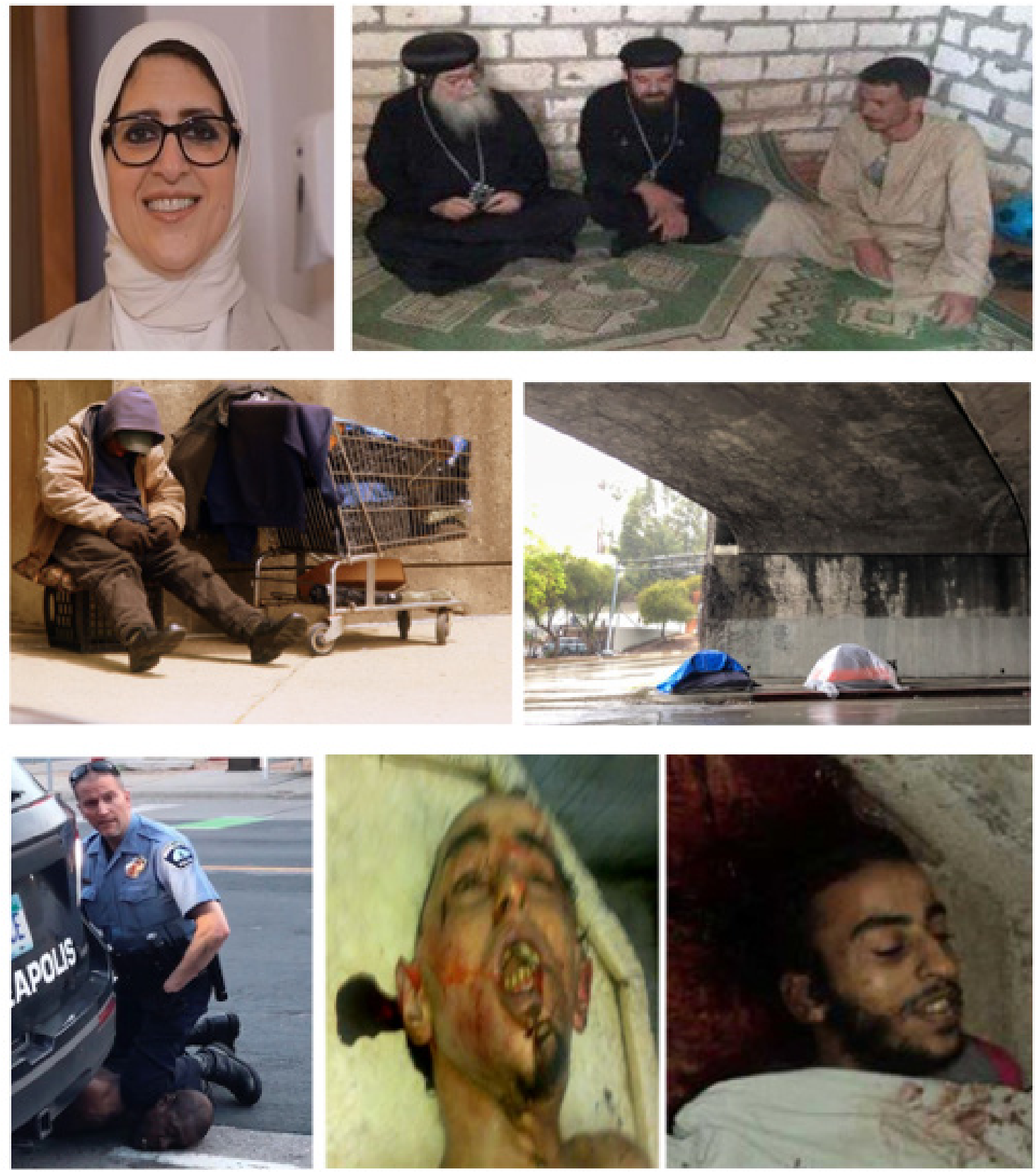

George Floyd USA 2020

Khaled M Saeed Alexandria 2010 Menas Daniel Maspero-Cairo 2011

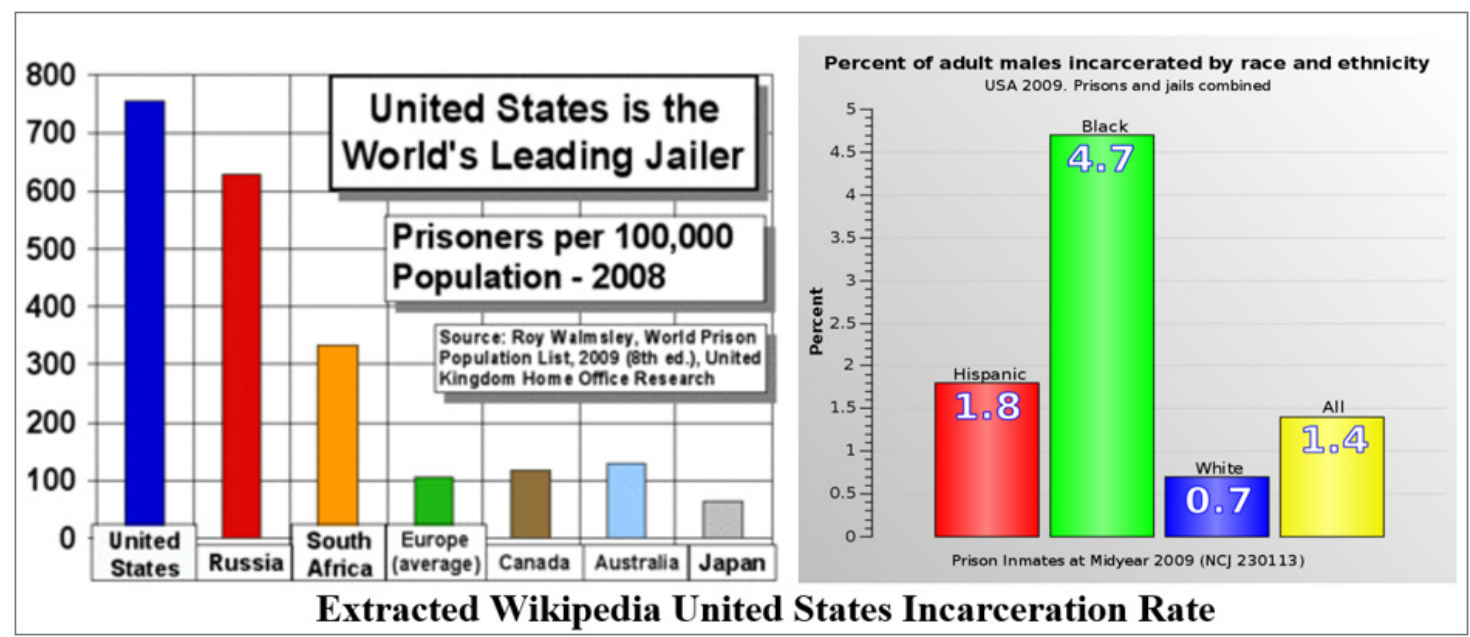

Figure 


\section{Acknowledgement}

To victims of cruelty: Khaled Mohamed Saeed Alexandria/ Egypt 2010, Menas Daniel (the Egyptian Guevara) Maspero-Cairo/ Egypt 2011 and George Floyd Minneapolis/ USA 2020. The sacrifice of Menas Daniel was ignored, at best unnoticed, by the concerned clergy lest it would expedite the exodus of their passive inmates off the grids to the never ending tales of afterlife. Nevertheless, their sacrifice delivered the "Annus Mirabilis-2013". The elected president is toiling to (a) liberalize Egypt from the well interwoven fabric of militant dogmatism which captivated the Egyptian brains and addicted their faculties to the notion of jihad as early as of Eisenhower 1953, Reagan 1985 and as of late Obama 2009, Patterson 2013 and (b) renew the resources of a hopelessly ruined environment by plastics, thus minimize, if possible at all, large scale polution of food ingredients and water supply with micro-plastics.

\section{Conflict of Interest}

No conflict of interest.
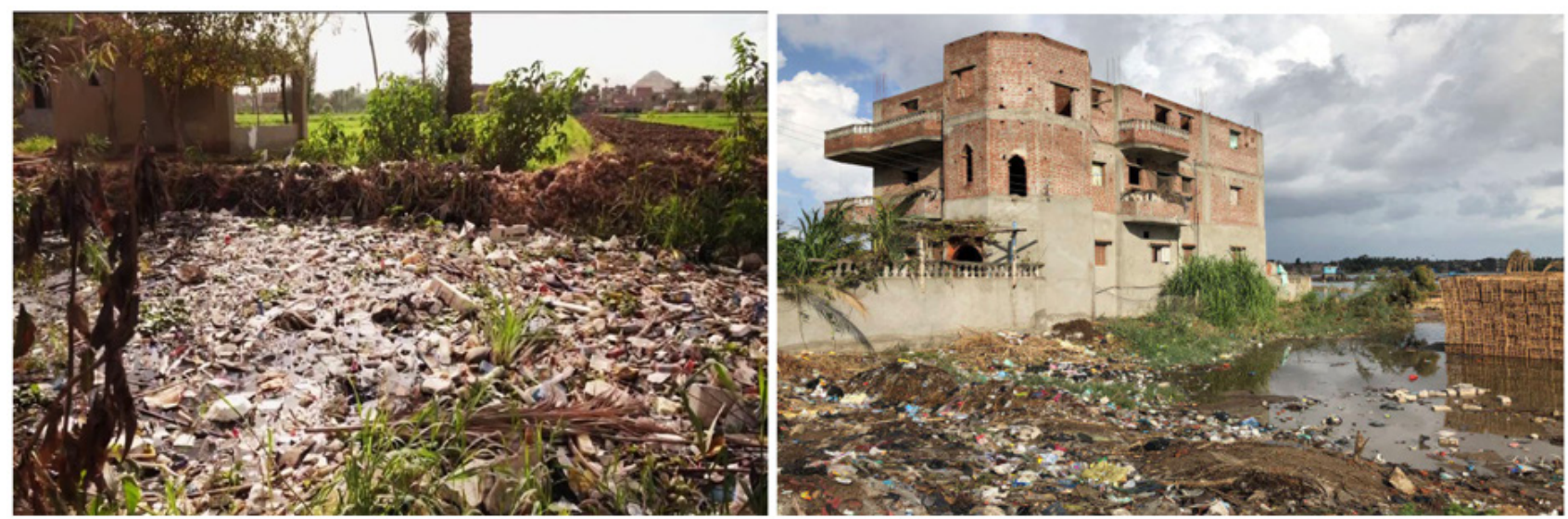

Egypt's environment: Replacing the green banks of the River Nile with expansive fields of plastics
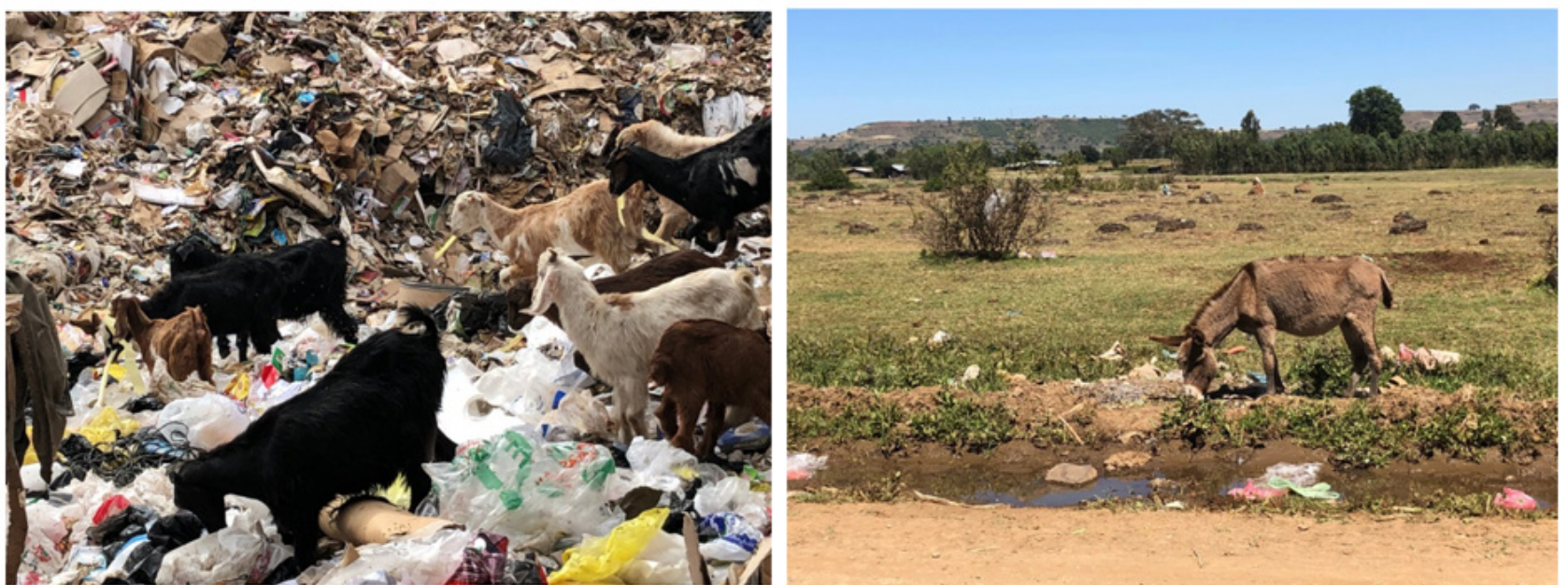

Health ruin of the Egyptians: Fields of micro-plastics pollution of animal and human diets.

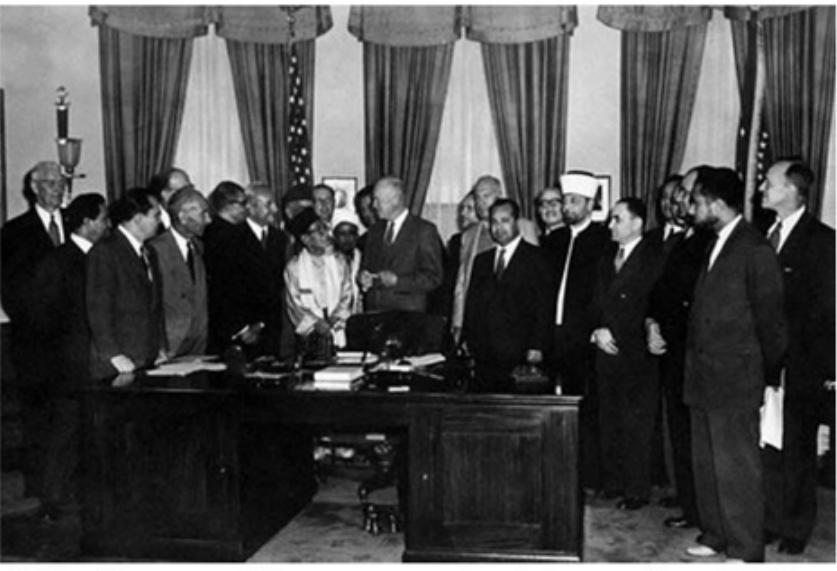

Eisenhower with proponents of dogmatism 1953

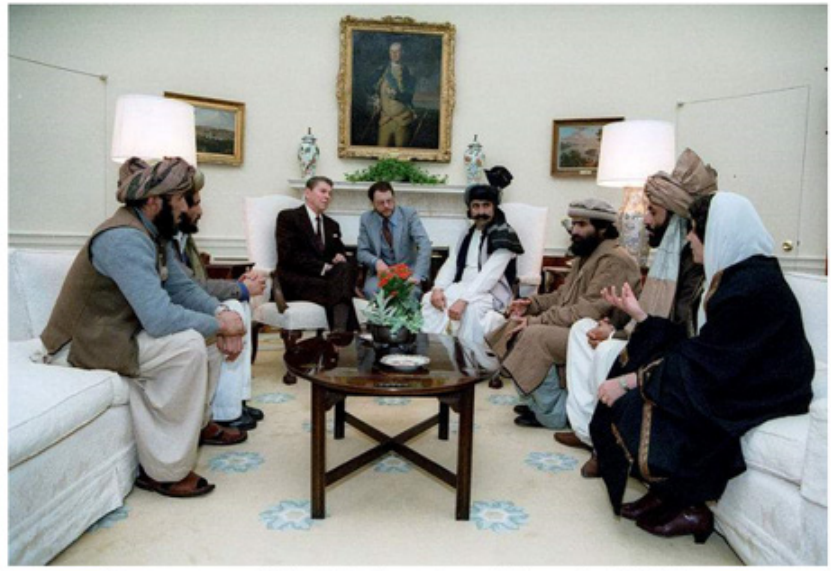

Reagan with Afghani militants 1985

Figure 


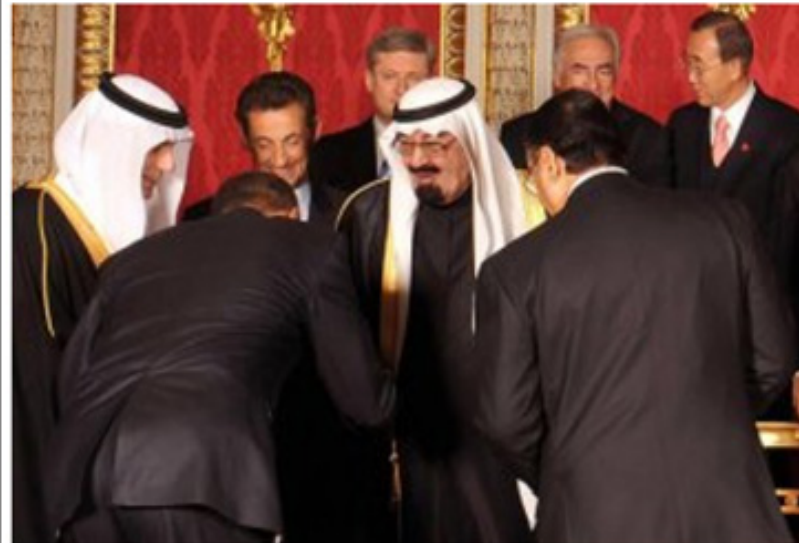

Obama's obedient salute to his amir 2009

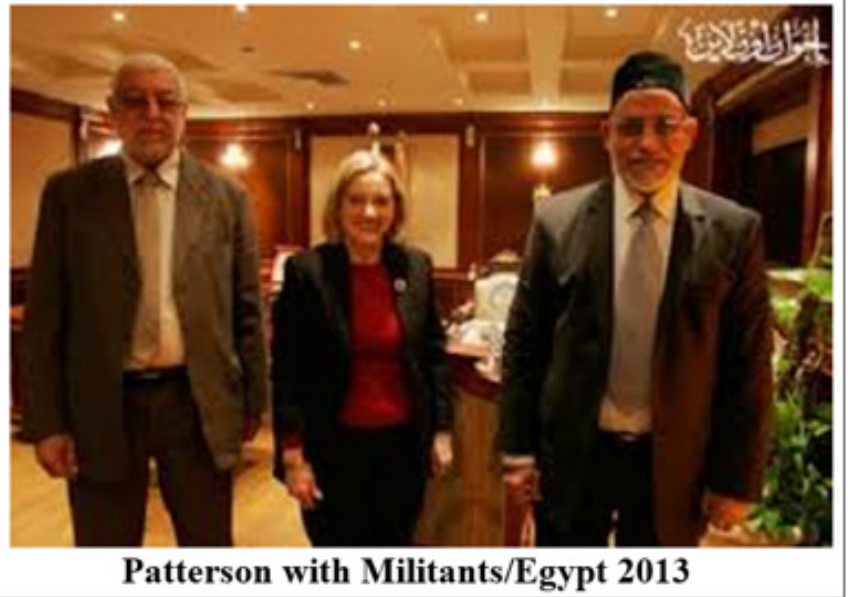

Patterson with Militants/Egypt 2013

Figure

\section{References}

1. C Zhang, W Zheng, X Huang, EW Bell, X Zhou, and Y Zhang. Protein Structure and Sequence Reanalysis of 2019-nCoV Genome Refutes Snakes as Its Intermediate Host and the Unique Similarity between Its Spike Protein Insertions and HIV1. J Proteome Res. 2020, 19: 1351-1360, and P Pradhan\$, AK Pandey\$, A Mishra, et. al., Uncanny similarity of unique inserts in the $2019-\mathrm{nCoV}$ spike protein to HIV-1 gp120 and Gag. Posted online Jan. 31, 2020, https://www.biorxiv.org/ content/10.1101/2020.01.30.927871v1.full.pdf.

2. XW Zhang, and Y Yap. Structural similarity between HIV-1 gp41 and SARS-CoV S2 proteins suggests an analogous membrane fusion mechanism. J Mol Structure (Theochem). 2004, 677: 73-76.

3. JH Xiao, P Rijal, L Schimanski, AK Tharkeshwar et. al. Characterization of Influenza Virus Pseudotyped with Ebolavirus Glycoprotein. J Virology. 92: 1-18, 2018, WF Klietmann and KL Ruoff. Bioterrorism: Implications for the Clinical Microbiologist. Clin Microbiol Rev. 14: 364-381, 2001; S Das and VK Kataria. Bioterrorism: A Public Health Perspective. Med J Armed Forces India. 66: 255-260, 2010 and S. Riedel. Biological Warfare and Bioterrorism: a Historical Review. Baylor University Medical Center Proceedings, 17:400-406, 2004.
4. WF Klietmann, KL Ruoff (2001) Bioterrorism: Implications for the Clinical Microbiologist. Clin Microbiol Rev 14(2): 364-381, S Das, VK Kataria (2010) Bioterrorism: A Public Health Perspective. Med J Armed Forces India 66(3): 255-260, and S Riedel (2004) Biological Warfare and Bioterrorism: a Historical Review. Baylor University Medical Center Proceedings 17: 400-406.

5. A Cullison, R Ballhaus and D Volz. Trump Repeatedly Pressed Ukraine President to Investigate Biden's Son. The Wall Street Journal, May 21, 2020.

6. G Sick (1991) The Election Story of the Decade. The New York Times.

7. E Roesch, A Amin, J Gupta, C García-Moreno, Violence against women during covid-19 pandemic restrictions. BMJ. Published online 2020 May 7.

8. COVID-19: We must fight harder to end violence against children, World Vision, Coronavirus Health Crisis. 